
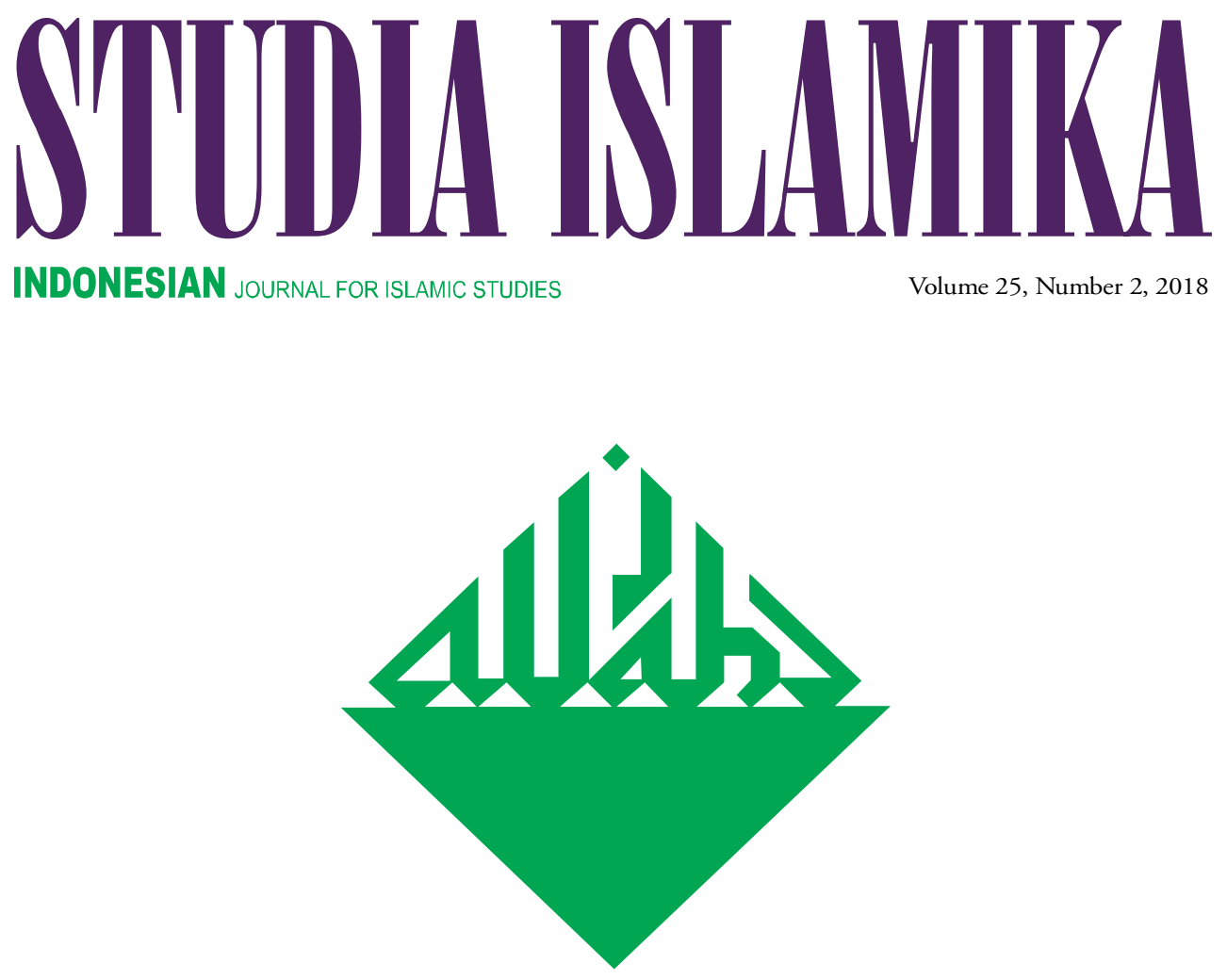

The Religiosity, Nationality, and Sociality of Pancasila: Toward Pancasila through Soekarno's Way Yudi Latif

Converting Belief, Connecting People: The Kingdoms and the Dynamics of Islamization in Pre-Colonial Archipelago Jajat Burhanudin

INDONESIAN TRANSLATION AND APPROPRIATION of the Works of Shariati and Hanafi in the New Order's Islamic Discourses Mujiburrahman

Sickle as Crescent: Islam and Communism in the Netherlands East Indies, I9I 5-I 927 Lin Hongxuan 
STIUDLA ISLAMIIIKA 



\section{STIDIIA ISLAVIIIKA}

Indonesian Journal for Islamic Studies

Vol. 25, no. 2, 2018

EDITOR-IN-CHIEF

Azyumardi Azra

MANAGING EDITOR

Oman Fathurahman

EDITORS

Saiful Mujani

Jambari

Didin Syafruddin

Jajat Burhanudin

Fuad Jabali

Ali Munhanif

Saiful Umam

Ismatu Ropi

Dadi Darmadi

Jajang Jahroni

Din Wahid

Euis Nurlaelawati

INTERNATIONAL EDITORIAL BOARD

M. Quraish Shihab (Syarif Hidayatullah State Islamic University of Jakarta, INDONESIA)

M.C. Ricklefs (Australian National University, AUSTRALIA)

Martin van Bruinessen (Utrecht University, NETHERLANDS)

John R. Bowen (Washington University, USA)

M. Kamal Hasan (International Islamic University, MALAYSIA)

Virginia M. Hooker (Australian National University, AUSTRALIA)

Edwin P. Wieringa (Universität zu Köln, GERMANY)

Robert W. Hefner (Boston University, USA)

Rémy Madinier (Centre national de la recherche scientifique (CNRS), FRANCE)

R. Michael Feener (National University of Singapore, SINGAPORE)

Michael F. Laffan (Princeton University, USA)

Minako Sakai (The University of New South Wales, AUSTRALIA)

Annabel Teh Gallop (The British Library, UK)

Syafaatun Almirzanah (Sunan Kalijaga State Islamic University of Yogyakarta, INDONESIA)

\section{ASSISTANT TO THE EDITORS}

Testriono

Muhammad Nida' Fadlan

Abdullah Maulani

ENGLISH LANGUAGE ADVISOR

Benjamin J. Freeman

Daniel Peterson

Batool Moussa

ARABIC LANGUAGE ADVISOR

Ahmadi Usman

\section{COVER DESIGNER}

S. Prinka 
STUDIA ISLAMIKA (ISSN 0215-0492; E-ISSN: 2355-6145) is an international journal published by the Center for the Study of Islam and Society (PPIM) Syarif Hidayatullah State Islamic University of Jakarta, INDONESIA. It specializes in Indonesian Islamic studies in particular, and Southeast Asian Islamic studies in general, and is intended to communicate original researches and current issues on the subject. This journal warmly welcomes contributions from scholars of related disciplines. All submitted papers are subject to double-blind review process.

STUDIA ISLAMIKA has been accredited by The Ministry of Research, Technology, and Higher Education, Republic of Indonesia as an academic journal (Decree No. 32a/E/KPT/2017).

STUDIA ISLAMIKA has become a CrossRef Member since year 2014. Therefore, all articles published by STUDIA ISLAMIKA will have unique Digital Object Identifier (DOI) number.

STUDIA ISLAMIKA is indexed in Scopus since 30 May 2015.

Editorial Office:

STUDIA ISLAMIKA, Gedung Pusat Pengkajian

Islam dan Masyarakat (PPIM) UIN Jakarta,

Jl. Kertamukti No. 5, Pisangan Barat, Cirendeu,

Ciputat 15419, Jakarta, Indonesia.

Phone: (62-21) 7423543, 7499272, Fax: (62-21) 7408633;

E-mail: studia.islamika@uinjkt.ac.id

Website: http://journal.uinjkt.ac.id/index.php/studia-islamika

Annual subscription rates from outside Indonesia, institution: US\$ 75,00 and the cost of a single copy is US\$25,00; individual: US\$ 50,00 and the cost of a single copy is US\$ 20,00 . Rates do not include international postage and handling.

Please make all payment through bank transfer to: PPIM, Bank Mandiri KCP Tangerang Graha Karnos, Indonesia, account No. 101-00-0514550-1 (USD),

Swift Code: bmriidja

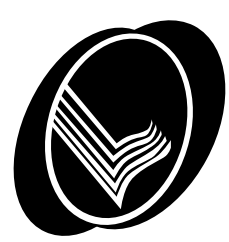

Harga berlangganan di Indonesia untuk satu tahun, lembaga: Rp. 150.000,-, harga satu edisi Rp. 50.000,-; individu: Rp. 100.000,-, harga satu edisi Rp. 40.000,-. Harga belum termasuk ongkos kirim.

Pembayaran melalui PPIM, Bank Mandiri KCP Tangerang Graha Karnos, No. Rek: 128-00-0105080-3 


\section{Table of Contents}

\section{Articles}

207 Yudi Latif

The Religiosity, Nationality, and Sociality of Pancasila:

Toward Pancasila through Soekarno's Way

247 Jajat Burhanudin

Converting Belief, Connecting People:

The Kingdoms and the Dynamics of

Islamization in Pre-Colonial Archipelago

279 Mujiburrahman

Indonesian Translation and Appropriation

of the Works of Shariati and Hanafi

in the New Order's Islamic Discourses

309 Lin Hongxuan

Sickle as Crescent: Islam and Communism

in the Netherlands East Indies, 1915-1927

351 Miswari

Mu'ḍilat al-aqlīyah al-Masịhìyah

fî ḥudūd balad al-sharīah al-Islāmīyah 


\section{Book Review}

405 Jajang Jahroni

Menemukan Haji Hasan Mustafa (1852-1930)

\section{Document}

423 Endi Aulia Garadian

Youth Camp for Preventing Violent-Extremism:

Fostering Youth Dialogue, Encountering Diversity 


\title{
Jajat Burbanudin \\ Converting Belief, Connecting People: The Kingdoms and the Dynamics of Islamization in Pre-Colonial Archipelago
}

\begin{abstract}
The pre-colonial Archipelago period of Indonesian history witnessed rapid Islamization. The kingdoms or sultanates served as the centre of emerging Islamic socio-political and cultural dynamics. In this article, the crucial role that the kingdoms played in facilitating Islamization will be examined, giving strong emphasis to how they emerged as hubs for 'ulamä' who Islamized the people of the Archipelago. This process created an Islamic network with the 'ulamä' introducing rulers and society to Islam. Islamization unified the people in the "lands below the winds" under one religion. This connecting process was further facilitated by the rise of Malay language alongside the Jawi (Arabic) script as a medium for intraregional communication as well as Islamic expression. The experience of being Islamized created a collective memory of being part of "the others" and laid a strong foundation for the unification of Indonesian society today.
\end{abstract}

Keywords: Islamic Kingdom, 'Ulamä, Islamization, Archipelago, Malay Language, Jawi Script, Religious Network. 
Abstrak: Nusantara masa pra-kolonial adalah satu periode penting dalam sejarah Indonesia yang menyaksikan proses Islamisasi yang intensif. Kerajaan atau kesultanan tampil sebagai pusat dinamika sosial-politik dan keagamaan. Dalam artikel ini, pembahasan diarahkan pada peran penting kerajaan dalam memfasilitasi proses Islamisasi, dengan menekankan pada proses historis bagaimana kerajaan menjadi rumah bagi para ulama; suatu prosesyang menciptakan satu jaringan keislaman di mana ulama berperan penting dalam memperkenalkan Islam kepada pengusa dan masyarakat. Islamisasi telah menghubungkan sebagian masyarakat "negeri di bawah angin" dalam satu agama. Dan hal ini diperkuat dengan tumbuhnya bahasa Melayu dan aksara Jawi sebagai media komunikasi antarkomunitas agama dan juga ekspresi Islam. Pengalaman Islamisasi ini telah melahirkan satu ingatan kolektif bahwa sebagian mereka menjadi bagian dari sebagian yang lain, dan pada akhirnya meletakkan dasar kesatuan bagi bangsa Indonesia dewasa ini.

Kata kunci: Kerajaan Islam, Ulama, Islamisasi, Nusantara, Bahasa Melayu, Aksara Jawi, Jaringan Keagamaan.

$$
\begin{aligned}
& \text { ملخص: شهدت نو ساتنارا ما قبل الاستعمار من التاريخ الإندونيسي الأسلمة السريعة. } \\
& \text { يتم استخدام الممالك أو السلطنات كمركز للديناميات الاجتماعية السياسية والثقافية } \\
& \text { الإسلامية الناشئة. وفي هذه المقالة، سيتم فحص الدور الحاسم الذي تلعبه المملكة في } \\
& \text { تسهيل الأسلمة. هذه العملية خلقت شبكة إسلامية مع علماء المدينة الذين أدخلو الحلكام }
\end{aligned}
$$

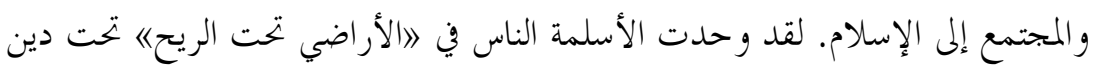

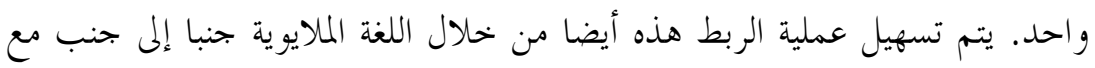

$$
\begin{aligned}
& \text { الكتابة الجاوية (العربية) كوسيط للتواصل داخل الإقليم بالإضافة إلى التعبير الإسلامي. }
\end{aligned}
$$

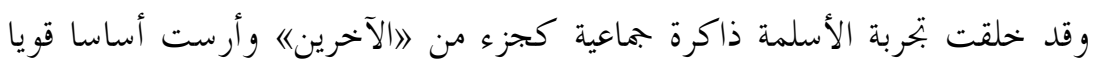

$$
\begin{aligned}
& \text { لتوحيد المجتمع الإندونيسي اليوم. وتله }
\end{aligned}
$$

الكلمات المفتاحية: المملكة الإسلامية، العلماء، الأسلمة، نوسانتارا، اللغة الملايوية،

$$
\text { النص الجاوي، الشبكة الدينية. }
$$


I

$\mathrm{n}$ the pre-colonial Archipelago, the kingdoms or the sultanates played a central role in the facilitation of Islamic dynamics. The kingdoms served as arenas where Islam was introduced to communities, alongside maritime commercial enterprises and political development. The kingdoms also facilitated the translation of Islam into religious institutions, such as qā $\bar{\imath} \bar{\imath}$ (judge) and Islamic learning centres, which strengthened the impact of its proselytization. As such, the establishment of the kingdoms is viewed as an important step in Islamic development, marking the rise of Islam as a socio-political and cultural phenomenon in Indonesia.

This article will discuss the process by which the kingdoms emerged as the hubs of 'ulamä' ('álim, Muslim scholar), who greatly contributed to the process of Islamization, which in turn facilitated contact and communication among the people of the Archipelago. In the precolonial period, most of the archipelagic regions - traditionally termed "the lands below the winds"-were the home of Islamic kingdoms. These kingdoms strongly engaged in the Islamization of people. The rulers made the advancement of Islam a central part of territorial expansion. In addition to that, the rulers also established institutions of Islamic learning within the kingdoms, where the ulam $\vec{a}$ were tasked with introducing Islam and educating new converts.

Thus, the rulers and the 'ulamä' contributed to connecting the people of the Archipelago who shared the same religious beliefs despite their diverse ethnicities, socio-cultural attitudes, and political backgrounds. Not only did they know each other as the residents of kingdoms in the lands below the winds, but they also shared the same Islamic faith. This process was reinforced by the common use of the Malay language in Jawi (Arabic) script, which was increasingly used in the Archipelago, and Southeast Asia, alongside the development of Islam. The Malay language played a crucial role as the lingua franca of the region, not only in trade and political diplomacy, but also in enhancing connections between people.

Despite the fact that conflict, war, and domination constituted one aspect in relations between the kingdoms during this period, the role they played in Islamization laid a strong foundation for what is acknowledged to have unified the diverse populations of modern Indonesia. Therefore, this article begins with discussing the important role that the kingdoms played as the heart of Islamic dynamics in the Archipelago. 


\section{Historiography of the Kingdoms}

Although written in a traditional style of narration, Sejarah Umat Islam (History of Muslim People) by Haji Abdul Malik Karim Amrullah (Hamka 1960) is significant. The last $\left(4^{\text {th }}\right)$ volume of the book was specifically dedicated for discussing the development of Islam in the Archipelago. Hamka (1908-1981), a leading 'älim of Indonesia who produced an extensive body of literature, viewed the kingdoms as the hub of Islamic dynamics in the region. Our knowledge about Islamic kingdoms in the Archipelago is attributed to Hamka's work.

The work of Uka Tjandrasasmita (1977) is also significant. In the third volume of Sejarah Nasional Indonesia — in which Tjandrasasmita was the editor-Islamic kingdoms were the main theme of discussion. The book was entitled with clear reference to issues about the kingdoms: for example, "The Period of the Growth and the Development of Islamic Kingdoms in Indonesia $( \pm 1600- \pm 1800)$ ". In addition to that, Tjandrasasmita also discussed the process of Islamization. While recognizing the important role of Sufism, as Johns (1961) asserts, in making Islam easily accepted by local communities, he also assessed another important factor that developed interpersonal relations in the process of Islamization, namely inter-matrimony of the local political elites (Tjandrasasmita 1977, 134).

Tjandrasmita's discussed Islamic kingdoms in a contributory chapter of a recent eight-volume book on Indonesian history, Indonesia dalam Arus Sejarah (Indonesia in the Course of History) with Taufik Abdullah and A.B. Lapian as the editors (2012). In the third volume of the book, sub-entitled "The Coming and the Development of Islamic Civilization" (Azra and Burhanudin 2012), a chapter is dedicated to discussing Islamic kingdoms in the Archipelago. Here, instead of underlining chronological growth (Burhanudin 2002), this chapter presents Islamic kingdoms from the perspective of the geographic spread of contemporary Indonesia, including Sumatra, Java, Nusa Tenggara, Maluku, Sulawesi and Kalimantan (Tjandrasasmita 2012, 20-59), while networks and inter-state relations were only minimally discussed.

The Islamic kingdoms were also examined by other scholars on certain regional foci. A work by de Graaf and Pigeaud (1985) about Islamic kingdoms in Java and another by Adnan Amal (2010a) on similar themes about the North Moluccas are noteworthy. De Graaf 
and Pigeaud were scholars who studied Javanese culture and society under the colonial framework of "Javanology" (Tsuchiya 1990, 8991; Uhlenbeck 1964). Despite their orientalist viewpoint (Roff 1985, 7-34; Said 1978), they laid a strong foundation for the historiography of the Javanese-Islamic kingdoms, producing the most referenced study on the subject. This seminal work analyzed Islamic kingdoms in the northern shore of Java in the $16^{\text {th }}$ to $18^{\text {th }}$ centuries, from Demak in Central Java to Giri-Gresik in East Java, and Banten and Cirebon in West Java. Their analysis is mostly based on traditional sources, especially babad, in addition to foreign sources, such as travellers' notes or the archives of the Dutch East Indies Company (VOC = Vereenigde Oost-Indische Companie) that are related to the leaders of the kingdoms. It is also important to note that this work had been written before both scholars were studying the most prominent kingdom in Javanese Islam, the Kingdom of Mataram (1958).

Adnan Amal is not part of the colonial project, nor specifically trained to study history. $\mathrm{He}$ is an expert in Islamic law, and was appointed as the chief of the higher court of Maluku in Ambon. He also teaches at the Law Faculty at the University of Khairum in Ternate. His work on Islamic kingdoms in the North Moluccas Islands is more about his concern and engagement in the history and culture of the area that he belongs to. Amal is a native Moluccas, and endeavoured to include his homeland in the formal historical study [of Islam] in Indonesia, much like Java and Sumatra which for a long time-in line with the colonial interest-have been the subject of scholarly studies (Boland and Farjon 1983). Therefore, despite "being presented in the form of a chronicle" (Lapian 2010, xxi), where academic rules are not strictly followed, the historical information in his book valuably fills a gap in our knowledge of the history of a region referred to by Arabic sources as Jazìrah al-Mamlūk or Moluco[s] in Portuguese. In his book, Amal presents the Islamic kingdoms in the spice-producing islandsTernate, Tidore, Bacan and Jailolo-as essential to determining the historical development of the Moluccas.

In this respect, an important period in the history of the Northern Moluccas was when the region was confronted with new European powers in the spice trade. Prior to being under the VOC and thereafter the Dutch colonial government, Northern Moluccas had become a contested arena for the trade monopoly of both the Portuguese and 
Spanish. The Portuguese came to Ternate in 1512, not long after the fall of Malacca in 1511 to the Portuguese. The Spanish harboured their ships nine years later (1521) in Tidore. The situation of the Moluccas under the Portuguese and Spanish was also discussed in another book authored Amal, Portugis \& Spanyol di Maluku (2010b). Here, Amal analyzes how the two European powers engaged in trade relations and the way they employed monopolistic policies that provoked conflict and wars. According to Amal, Portuguese and Spanish colonialism caused conflict, prolonged war, and contributed to economic impoverishment among the Moluccas people.

The Islamic kingdoms of the Archipelago were maritime in nature and strongly engaged in long distant trading and involved merchants from various countries in the world. Maritime trade in this region has been the subject of scholarly study. The seminal work by Anthony Reid, Southeast Asia in the Age of Commerce $(1988,1993)$ placed the kingdoms in Southeast Asia, including the Islamic kingdoms, in the context of maritime trade, which were formed on the basis of strong foundations in the structure (geographic and climatic conditions) and the conjuncture (social and economic relations), on which the birth of civilization in the region can be observed. Reid shared a historical study of the "Annales paradigm" (Stoianovich 1976) in the context of Southeast Asia.

Denys Lombard's work can be placed in the framework of the "Annales paradigm" (Lombard 1996). Unlike Reid, Lombard focused on areas of the Archipelago known as Java. However, like Reid, Lombard also views the Archipelago in the context of its engagement in international maritime trade, which led it to be a meeting point among major civilizations-including China, India, and Europe. Lombard asserts that the Islamic kingdoms are to be viewed not only as political institutions, but also, and more importantly, as the sites of an emerging new society with urban and cosmopolitan values.

Above all, the important role that the kingdoms played in Islamic development can be attributed to how they served as the home of the ulam $\vec{a}$. In the pre-colonial Archipelago, the 'ulam $\vec{a}$ were socio-religious elites who were responsible for Islamic adherence in the kingdoms. This was evident in the kingdom of Samudra Pasai. Ibn Battuta, who visited the kingdom in the fourteenth century, reported that the ruler, Mălik alZāhir, was in favour of Islamic learning. Mālik al-Zāhir was described as 
"one of the noblest and the most generous of kings, a Shāfi' $i$ in madhhab, and a lover of jurists, who comes to his audience for recitation and for discussion" (Battuta 1994, 876-77).

Moreover, the leading 'ulam $\vec{a}$ ' of the Archipelago in the $17^{\text {th }}$ and $18^{\text {th }}$ centuries established their careers in the kingdoms. As studied extensively by Azra (2004), the Aceh kingdom in Sumatra emerged as the site where leading 'ulamä such as Hamzah Fansuri (d. 1527), Shams al-Dīn al-Sumatrāī (1603), Nūr al-Dīn al-Ranīī (d. 1608) and 'Abd al-Ra'üf Singkel (d. 1693) served as Shaykh al-Isläm - the highest advisory position under the ruler-and qā Under its economic and political power, the kingdom provided these 'ulam $\vec{a}$ ' with the facilities and support to gain intellectual achievement and in turn to integrate Islam with the socio-political and cultural life of the people of Aceh and of the Archipelago in general.

The 'ulam $\vec{a}$ ' introduced a new vision to the 'lands below the winds'. In addition to converting the people to Islam, the 'ulamä also facilitated a new term for the Archipelago, which had been known to the Arabspeaking community as Jāwa or Biläd al-Jäwah. This is particularly the case with the 'ulamä who had a connection with Mecca, who were described and self-identified asas Jawi fellows (așhāb al-Jāwììn) (Burhanudin 2007, 20-24), signifying that the lands below the winds is a distinct Muslim ecumene (Laffan 2003, 17-18). The term jawa evolved to denote a cultural marker which bound the Archipelago under Islamic characteristics, the Malay language and Jawi (Arabic) script. For instance, this is expressed in the Bustān al-salāținn by Nūr al-Dīn al-Ranīīi, a leading 'álim. Al-Ranīrī used the term Jawi to denote the emerging Malay language in the Archipelago. He wrote that Iskandar Thānī (the ruler of Aceh and his patron) commissioned him "to compose a book (kitāb) in Jawi (Malay) language" (Grinter 1979, 10). I will deal with the issues of language and script later. I will now discuss the role of the kingdoms and the 'ulama' in the Islamization of the Archipelago.

\section{The Dynamics of Islamization}

The kingdom of Samudra Pasai in Sumatra is of special importance in Indonesian Islam. Established in 1297, it is one of the earliest Islamic kingdoms to ever exist in the Archipelago, at a time when Islam began to emerge as a political power. The formation of this kingdom 
marked an important period of Islamization, during which Islam began to be integrated into politics alongside the engagement of people in the north coast of Sumatra, the site of the kingdom, in international maritime commerce. Thus, a salient feature of Islam in the pre-colonial Archipelago - the integration of Islam, politics and trade-began to appear with the rise of the kingdom of Samudra Pasai.

The importance of Samudra Pasai can also be seen in its contribution to the process of Islamization. As Tome Pires (1944, 241-42 Vol. 1) notes, the ruler of Samudra Pasai played a central role in the conversion of Malacca's ruler, Iskandar Shah, to Islam, who followed the advice of the ruler of Samudra Pasai and the 'ulamä' who had settled there during his reign. He converted to Islam when he was seventy-two years old. At that time, in the early $14^{\text {th }}$ century, Malacca was emerging as a new centre for trading activities, gradually surpassing the role of Samudra Pasai. Supported by Iskandar Shāh, who was very happy to welcome the Muslim merchants, providing them with facilities for both economic and religious activities, Malacca became increasingly attractive for merchants from the Archipelago or those from foreign regions who had regularly visited Samudra Pasai. Some Muslim Merchants, particularly Persians as well as Bengalis and the Arabs, moved from Samudra Pasai to Malacca (Pires 1944, 240-41 Vol. 2)

The role that Samudra Pasai played as the centre of Islamic development was also recognized in Java. The story of wali songo-nine ulam $\vec{a}$ (wali) who were responsible for Islamization in Java-were also involved with Pasai in Sumatra. Sunan Gunung Jati of Cirebon, Sunan Giri of Gresik in East Java, and Sunan Kudus of Central Java were believed to be descended from a great 'álim in Pasai, Shaykh Maulana Ishak, and as having learned Islam with the 'alim. From there, they then spread Islam in Java (Saksono 1996, 34-45). Samudra Pasai was traditionally respected for being the centre of Islamic learning, although its position was declining in terms of politics and economics, as it was being gradually replaced by the Malacca kingdom.

The trend of Islamization continued during the Malacca kingdom in the $14^{\text {th }}$ century, which was integrated into the kingdom's territorial expansion. This process began during the reign of the third ruler, Sultan Muzaffar Shāh (d. circa 1459), who was responsible for extending the Malaccan territories beyond the kingdom area established under the first three rulers. He incorporated Kedah and Selangor into his realm, 
as important sources of tin and foodstuffs for Malacca. With the same intention, he also took the town of Sungai Batu Pahat along the River Formosa, a large river which functioned as an artery for the sea transportation of goods for sale (Pires 1944, 243-44 Vol. 2). Quite separate from their supply function, these areas were important elements for the accumulation of Malaccan power in its bid to monopolize trading activities in the Strait of Malacca (Wealthly 1964, 140). The expansion of Malacca was conducted similarly to Srivijaya, in the sense that the Malaccan ruler implemented the policy of monopolizing the strait (Wealthly 1964, 127; Wolters 1970, 174). From these areas, he then expanded the territories to Bentan, Pahang, Trengganu, and Patani. Campaigns against Kampar and Indragiri in the land of Minangkabau in West Sumatra were also conducted to secure gold supplies for the Malacca kingdom (Pires 1944, 244-45 Vol. 2; Wealthly 1964, 140).

The territorial expansion of Sultan Muzafar Shah was accomplished by his successor, Sultan Manșūr Shāh (d. 1477). He added Bernam and Perak into the Malaccan domain, and also conquered Siak on the east coast of Sumatra. Subsequently, other areas in Sumatra, such as Rupat, Jambi and Bengkalis also fell under Malaccan control (Wealthly 1964, 142). Malacca became so powerful during this period that Sultan Manșūr Shāh has been credited as "marking the apogee of Peninsular Malay power and culture" (Pires 1944, $249 \mathrm{Vol}$. 2). The great territorial domain of the Malacca kingdom lasted until the reign of the last ruler, Sultan Mahmūd Shāh (1488-1511) when the kingdom was conquered by the Portuguese in 1511 .

In this context, what is important to note is that the territorial expansion occurred in line with the attempt to convert societies subjugated to Islam. Almost all areas which were subjected to the control of the Malaccan state became Muslim partly as a result of the power expansion of the Malaccan rulers. The efforts of Sultan Muzaffar Shāh to conquer Pahang, for example, was inspired by the ruler's conversion to Islam. The same policy can also be found in other areas instigated by other Malaccan rulers. The policy of territorial expansion operated in the same breath as Islamization. By combining the quest for expansion with Islamization, the Malaccan rulers gained political support, alongside great economic advantage, from other Muslim trading countries. The rulers became so famous that they attracted the attention of the Muslim kings of Aden and Ormuz in Middle Eastern countries, Cambay and Bengal in India, all of whom sent 
many merchants to live and conduct business in Malacca (Pires 1944, $245 \mathrm{Vol} .2$ ). The same advantages were also acquired from the areas they conquered. As aforementioned, these areas produced commodities which were needed by Muslims merchants who came to trade in Malacca, such as tin, gold, nutmeg, and pepper. These products were in great demand in international markets (Hall 1985, 228-29; Reid 1993, 2-10).

The same process of Islamization also occurred in the kingdom of Aceh in the $16^{\text {th }}$ century. This kingdom emerged under the leadership of its first ruler, Sultan Ali Mughayat Shāh (1514-1530), who was able to take advantage of changing circumstances in the region after the fall of Malacca to the Portuguese. He welcomed Muslim merchants, who avoided Portuguese hostility in Malacca, to transfer their business to Aceh. He succeeded in his efforts. During his reign, there was a significant increase in the number of Muslim traders, primarily from west Asia, including the Gujaratis, who visited Aceh and formed a major contributing factor in the advancement of trade in the kingdom (Lombard 1986, 47-48). In order to increase the collection of produce for the growing merchants, Ali Mughayat Shāh began to expand the kingdom's territories and dominion. He conquered pepper producing areas in Sumatra, Daya, in 1520 and a few years later (1524) in Deli, Pedir and Pasai. The last area was captured after successfully defeating the Portuguese naval force close to Pasai (Lombard 1986, 49). As in the case of Malacca, territorial expansion by Ali Mughayat Shāh occurred alongside the process of Islamization. Economic motives were closely intertwined with religious zeal. For instance, the people of Daya had not yet been converted to Islam until the area was under Acehnese political power (Pires 1944, 163 Vol. 1).

The spirit of Islamization is well demonstrated in territorial expansion during the reign of Sultan 'Alauddīn Ri'āyat Shāh al-Qahhār (15371571), who laid a strong foundation for Aceh's ascendency to power and role in commerce in the western Archipelago. He was reported to have attacked the Batak people in the southern area of Aceh in 1539 with the intention of converting them to Islam. This attack was unsuccessful, even though it was aided by troops from Turkey, Cambay, and Malabar. Military attacks were also mounted against the Portuguese in Malacca three times (in 1537, 1547 and 1568), but were again unsuccessful. In 1564, Aru was also captured, following the conquest of Johor in the Peninsula (Dasgupta 1962, 47; Lombard 1986, 50). Nevertheless, what 
is more important to note is the expansion of Aceh to the Minangkabau area in the west coast of Sumatra, where the Islamic campaign was intensified-alongside control over local produce-which established the future role of the area as a hub of 'ulam $\vec{a}$ ' who were responsible for Islamizing the people of Sulawesi and beyond.

As studied extensively by Kathirithamby-Wells (1969), the west coast area of Sumatra had been visited by west Asian Muslim traders since the $14^{\text {th }}$ century. The Gujaratis, who looked for gold and pepper, were the main traders. A Portuguese trader who visited the area in 1519 reported that five Gujarati vessels at Barus treated him with hostility (Kathirithamby-Wells 1969, 456). However, the presence of Muslim merchants did not seem to have made a great impact in terms of Islamization. Until the early $16^{\text {th }}$ century, only the ruler of Tiku who was rumoured to be a Muslim, while the rulers of Singkel and Pariaman were still considered to be heathens (Pires 1944, 160-61 Vol. 1). Intensive Islamization began to occur as the Aceh kingdom established strong political connections with the west coast, which existed during the reign of Sultan 'Alauddin Ri'āyat Shāh al-Qahhār. For instance, the Sultan appointed his family members as Aceh's key representatives in the regions in order to provide the kingdom with the manpower necessary to exert control and hegemony over the west coast. In addition to Barus, the ruler of which was married to the Sultan's sister, Sultan Alauddin also appointed his two sons as the rulers (royal representatives) of Aru and Pariaman, with the titles Sultan Ghori and Sultan Mughal respectively (Kathirithamby-Wells 1969, 457).

As a result, the west coast area of Sumatra, particularly Pariaman, emerged as the gateway through which the Islamic influence penetrated the world ('älam) of Minangkabau. Aceh was responsible for large-scale Islamization, which is considered to have occurred in the mid- $16^{\text {th }}$ century. This process continued to advance, alongside the establishment of Aceh's political hegemony and strong economic control, culminating during the reign of the greatest ruler of Aceh, Iskandar Muda (16071636). The Islamic intellectual network between Aceh and West Sumatra was well founded, and the transmission of Islam was also established, which can be seen in the story of a great 'alim of Minangkabau in this period, Burhanudin of Ulakan (1646-1704). He is known as to have learned Islam — and followed Sufi order (tarekat) of Shațtāinyahfrom a celebrated 'àlim of Aceh, 'Abd al-Ra'üf Singkel (1615-1693). 
After having studied with al-Sinkili for several years, Burhān al-Dīn established surau, a Sufi-cum-educational institution in Ulakan, which came to be the basis for the further Islamization of the Minangkabau people (Azra 1990, 64-85).

In this study, the significance of Islamized Minangkabau lies in the fact that it served as the centre of emerging 'ulam $\vec{a}$ who engaged in a mission of Islamizing people in other areas in the lands below the winds. The Islamization of south Sulawesi is a well-known example. Although not recorded in Malay sources, the traditional text of South Sulawesi (lontara) recounts the Islamization of the area in relation to the coming of three 'ulamä'(dato) from Minangkabau. 'Abd al-Ma'mūr (later known as Dato ri Bandang) was the first 'alim who landed in Makassar, sometime around 1576. He tried to spread Islam in the kingdom of Gowa-Tallo, but without success. He continued the mission few decades later, in the beginning of the $16^{\text {th }}$ century, accompanied by two other 'ulamä', Sulaymān (known as Dato ri Pattimang), and 'Abd al-Jawad (Dato ri Tiro). However, they again experienced difficulties with converting the ruler to Islam. Therefore, they decided to start the mission of Islamization from the kingdom of Luwu (Mattulada 1983, 230; Pelras 1985, 119).

This decision proved to be highly strategic. As the oldest kingdom in South Sulawesi, Luwu was believed as to have special position in the traditional belief of Bugis-Makassare people, and the rulers of other kingdoms, as "the cradle of South Sulawesi nobility and the central place in the myth of origin" (Pelras 1985, 119). Thus, after successfully converting the ruler of Luwu, La Patiware' Daeng Parabu, and his royal family to Islam in 1603, the three 'ulamä' gained a strategic ingress to Islamize the kingdoms and people of South Sulawesi.

Unlike the other two 'ulam $\vec{a}$ mentioned-Dato ri Pattimang and Dato ri Tro who spent his lifetime in Luwu and Tiro (Bulukumba) respectively_Dato ri Bandang, not long after staying in Luwu, went to Makassar to resume his mission of converting the ruler of Gowa-Tallo. He succeeded in 1605. Karaeng Matoya or I Mallingkaang Daeng Mannyonri, the ruler of Tallo and the prime minister (mangkubumi) of Gowa, was the first ruling elite in South Sulawesi who converted to Islam in 22 September 1605, acquiring the Islamic name Sultan 'Abdullāh Awwal al-Islām. His conversion was followed by the ruler of Gowa, I Manngarangi Daeng Manrabbia, who was nineteen years old 
at the time, and took the title of Sultan Alauddin (Mattulada 1983, 220).

The conversion of Karaeng Matoya was of special significance because it was believed to be a of rite of passage in the Islamization of South Sulawesi. It is therefore preserved in legendary stories that still live today in the collective memory of local people. One story relates that once in 1605 an 'álim from Minangkabau in West Sumatra, Abdul Makmur (Dato ri Bandang), landed in the port of Tallo. After performing a prayer, which attracted the attention of local people, he informed them that he intended to meet the ruler of Tallo. Notified about the arrival of a mysterious man (orang ajaib), the ruler immediately went to the beach. When he was at the gate of the kingdom's palace, he met an old man who asked about his intention of walking out of the palace; he then wrote something down on the nail of the ruler's thumb, asking him to tell his greeting to the mysterious man at the beach. Abdul Makmur knew that what was written on the nail of his thumb was a Qur'anic verse (al-Fätihah). He also informed the ruler that the old man he met was a personification of the Prophet Muhammad. Immediately after seeing 'Abd al-Ma'mūr, the ruler converted to Islam and proclaimed his religion to the people of Makassar (Mattulada 1983, 221; Noorduyn 1956, 90).

The above story, being legendary in nature, does not explain the reasons and circumstances in which Karaeng Matoya decided to convert to Islam. It is due to the fact that almost two years before (in 1603), Datu ri Bandang had found it difficult to convince the ruler to convert to Islam. In this context, the conversion of Dato' (ruler) of Luwu seems to be the best explanation. As the oldest kingdom in South Sulawesi, Luwu remained much respected, where excellence (kemuliaan) still existed, amid the rising power of Gowa-Tallo (Mattulada 1983, 231). It is most likely that Karaeng Matoya, who had refused to convert to Islam, was already familiar with Muslim communities-primarily traders from Pahang, Patani, Johor, Campa, and Minangkabau-who had come to and stayed in the coastal regions of Gowa-Tallo and other kingdoms in South Sulawesi. ${ }^{1}$ Therefore, the legendary story relates to the fact that Karaeng Matoya had already greetedDato ri Bandang, who had just landed in Makassar, with the Muslim salutation al-salam alaykum wa raḥmatullāh wa barakātuh, just before he proclaimed his conversion to the Islamic faith (shahädah) (Pelras 1985, 12-21). 
As such, the experience of Dato ri Bandang is illustrative of the way that the kingdom contributed to the advancement of Islamization. The conversion of Karaeng Matoya strengthened the Islamization process, which had previously been confined to community aspirations, to the extent that Islam was later adopted as the formal religion of the kingdom. ${ }^{2}$ Two years his conversion, on 9 November 1607, the first Friday public prayer was held at a newly founded mosque, confirming that Gowa-Tallo had become a Muslim kingdom. Gowa-Tallo emerged as the kingdom that accelerated the process of Islamization. In line with its rise as the most powerful kingdom in South Sulawesi, Gowa-Tallo engaged in Islamizing other kingdoms, a process that was intertwined with economic interests in local produce among international traders in the capital of the kingdom. In some cases, the Islamic campaign of Gowa-Tallo was well accepted. However, it also had to confront strong opposition from the Buginese kingdoms (Bone, Wajo, and Sopeng). To these kingdoms, Gowa-Tallo waged the so-called "Islamic wars" and succeeded. The kingdoms were conquered and Islamized. Thus, in 1608 Sawitto, Bacukiki, Suppa, and Mandar in the west coast, and Akkotengeng and Sakkoli in the east coast, fell under Gowa-Tallo control. One year later, in 1609, Sidenreng and Soppeng, and then Wajo in 1610, were seized. The last kingdom Gowa-Tallo conquered was Bone in 1611. Almost all the areas in South Sulawesi were Islamized in this period (Mattulada 1983, 225; Pelras 1985, 109).

The Islamization of Kutai in East Kalimantan, which is believed as to have occurred in the early $17^{\text {th }}$ century, during the reign of Raja Mahkota (1575-1610), the sixth ruler of Kutai kingdom, is related to the 'ulam $\vec{a}$ of Minangkabau. The local text on the history of Kutai, Salāsilah Kutai (Kutai Chronicle), relates that the process of Islamization began with the coming of two 'ulamä from Minangkabau, Tuan di Bandang (most likely Dato ri Bandang, already explained) and Tuan Tunggang Parangan. After converting the people of Makassar to Islam, both agreed to continue the mission of Islamization in the kingdom of Kutai. However, due to the religious reversion of Makassare people, Tuan di Bandang returned there, leaving the duty of the Islamizing mission in Kutai to the hands of Tuan Tunggang Parangan.

Following the folk story in Salasilah Kutai (Jones 1979, 147-48; Mees 1935, 240-44), it is narrated that the 'alim, Tuan Tunggang Parangan, once went into the court and began to persuade the ruler 
to embrace Islam. After listening to the speech of the 'alim, the ruler replied by asking about the power (kesaktian) the 'alim had: "if your power proves to be superior to mine I will certainly comply with what you ask, but if mine is the equal of yours I will not”. Both agreed to fight in a battle of power (adu kesaktian), which the 'álim won. Having been defeated, the ruler addressed the 'álim, "I will comply", although he asked for a little more time in order to finish [eating] pork. Afterwards, the ruler went to the a'lim, who gave him the instruction of Islamic faith, so that he could become a firm believer. After that, the chiefs, nobles, and finally the people converted to Islam. The ruler attacked any countries that failed to accept the faith and Islamized them after being defeated.

There is another story about the kingdom of Banjarmasin in south Kalimantan. The Islamization of the area is attributed to the kingdom of Demak in Java, which was invited to intervene in the political affairs of Banjarmasin. As is recounted in the Hikayat Banjar (Ras 1968), the story began as Pangeran Samudra, who had established himself as a ruler of Banjarmasin, was attacked by his uncle Pangeran Tumanggung, who contended for the throne. Under the advice of his counselor, Pangeran Samudra sought assistance from the Sultan of Demak in Java. He sent Patih Balit as an emissary from Banjar, who arrived at the court of Demak with a letter stating that Pangeran Samudra "begs to be favoured with aid and support". The sultan of Demak said: "I am willing to help, providing [that] my son [Pangeran Samudra] the king of Banjarmasin becomes a Muslim. If he does not want to embrace Islam, then I do not wish to help". Responding to the sultan's request, Pangeran Samudra and his deputies (patih) were ready to become Muslims. The sultan, in return, deployed one thousand auxiliary troops with equipment. He also sent religious officials of the kingdom, panghulu, to oversee the conversion (Jones 1979, 146-47; Ras 1968, 427-31).

The decision of Pangeran Samudra was not without strong reason. It refers most likely to the period during the reign of its third ruler, Sultan Trenggana (r. c. 1505-18 and c. 1521-46), who developed Demak extensively, in terms of both political power and Islamization. He conquered the capital of Majapahit in Kediri in $c .1527$ (Graaf and Pigeaud 1985, 58-67), signalling the establishment of Islamic political power in Java and thus replacing the Hindu-Buddhist kingdom. Other kingdoms that were of special importance include Banten and Cirebon 
in West Java. The establishment of these two kingdoms is closely associated with Sunan Gunug Jati (d. c. 1570), a respected 'álim and one of nine Javanese wali. ${ }^{3}$ Nūrullāh, Sunan Gunung Jati's former name, began his career as a political advisor for Trenggana. He is considered to be the main agent behind Demak's military expansion and control of Banten from the local lord of Pajajaran. Not long after, around 1552, he moved to Cirebon to expand Islamic political power on the north coast of Java. Here, he ruled Cirebon as another Islamic kingdom, and established it as a centre for the spread of Islam to the areas of West Java (Graaf and Pigeaud 1985, 138-50).

Thus Banjarmasin added to the list of the areas where Trenggana established his power, alongside Islamization. In addition to becoming Muslim, the ruler of Banjarmasin accepted being a vassal of Demak. He sent an envoy annually, with a huge amount of tribute, to the kingdom of Demak (Graaf and Pigeaud 1985, 68). ${ }^{4}$ And, as is expected, the Islamic kingdom of Banjarmasin in turn acted as an instrument of Islamization in neighbouring areas in south Kalimantan.

Another kingdom in Java that had made a great contribution to Islamization was Giri-Gresik in the eastern part of the island. In the $16^{\text {th }}$ century, Giri-Gresik emerged as a leading Islamic kingdom as well as an important port in the international trade network. Tome Pires (Pires 1944, 193 Vol. 2) described it as "the jewel of Java in trading ports", signifying its crucial importance as both a trade centre and a major centre of Islam. Giri had been the site of Sunan Giri, a leading 'álim and one of the nine wali of Java, who then became the ruler of Gresik. Thus, Giri-Gresik developed as a kingdom with the 'ulam $\vec{a}$ as the rulers (priester-vorstendom). This kingdom reached its apogee under the reign of Sunan Prapen $( \pm 1548-1605)$ (Graaf and Pigeaud 1985, 185-89). During this period, Giri-Gresik became the centre of Islamization in the eastern part of the Archipelago.

Ternate in Moluccas was a kingdom that had a strong Islamic relationship with Giri-Gesik in the early $16^{\text {th }}$ century. It was related to the coming of Datu Mawlānā Husayn, an 'àlim from Minangkabau who had stayed and learned Islam in Giri-Gresik. ${ }^{5}$ He helped facilitate the process of Islamization, which had already begun in the mid- $15^{\text {th }}$ century with the conversion of the ruler (kolano) Marhūm (14651485). In line with the influx of Muslim merchants from west Asia-a major contingent of traders who came to the kingdom for spice- 
Ternate during the reign of Marhum had already become familiar with Islam and the Muslim community. It was the converted ruler who, besides urging the elites (babato) to become Muslims, provided Islamic education for his son and his future successor, Sultan Zayn al'Ābidīn (1468-1500). With the assistance of Datu Mawlānā Husayn, young Zayn al-Ā̉bidinn was sent to Giri-Gresik to learn Islam from the aforementioned 'álim, Sunan Giri (Amal 2010a, 59-63).

Therefore, when Zayn al-Ābidin returned to Ternate, he took with him several Muslims from Java, most probably fellow students of Sunan Giri, to be appointed as religious teachers, imam masjid (prayer leaders in mosques), and other positions to strengthen the Islamization of the kingdom. Known later as imam Jawa (Javanese guru), they contributed to the formation of a religious community. In order to uphold the Islamification agenda within the kingdom they founded special officials for Islamic affairs, locally called as Babato Berjubah Putih, which consisted of a judge $(q \bar{a} d \bar{\imath})$, grand imam, and those responsible for handling Islamic affairs in the kingdom (Amal 2010a, 64). Since then, the kingdom of Ternate, together with other kingdoms in Moluccas-notably Tidore, which was Islamized in approximately the same period as Ternateengaged in Islamizing the people in the eastern part of the Archipelago.

Another area that had an Islamic relationship with Giri-Gresik was Lombok in West Timor, also known as Nusa Tenggara Barat. In this region, unlike in Ternate where Giri-Gresik served as a centre of Islamic learning, the ruler of this priester-vorstendom directly engaged in Islamization. It was Sunan Prapen who is believed as to have propagated Islam among the people of Sasak. He started his mission in Bayan, an area in Lombok where he introduced Islamic Sufism to local people. From there, he continued Islamizing the people of Sumbawa and Bima (Budiwanti 2007, 287). In this respect, Sunan Prapen was not the first 'álim-cum-ruler who came to Lombok. The local people of Bayan believe that Sunan Prapen continued what Sunan Ampel (one of nine wali) from Surabaya had already initiated, who had established Bayan as an area to begin the mission of Islamization. According to local tradition, the springs in Bayan, locally known as Lokok Jawa, Ampel Duri and Ampel Gading, are associated with the presence of Sunan Ampel in the area (Budiwanti 2007, 289). ${ }^{6}$

It is also important to discuss is the kingdom of Buton in central Sulawesi. There are many versions about how and when the kingdom 
was Islamized, one of which attributes Islamization to the territorial expansion of Ternate. Ternate under the reign of Sultan Bābullāh (1570-1583) became a powerful kingdom. Bābullāh made a series of conquests to areas in the eastern Archipelago. In 1575, he successfully captured Gamlamo fort and expelled the Portuguese to Ambon. One year later, in 1576, he conquered Hoamal, Buru, Manipa, Ambalau and Buano, closing the areas to business with the Portuguese. Not long after, he extended the kingdom's territories to the east coast of Sulawesi: Banggai, Tiboro, Tobungku and Pangasin. At around 1580 Bābullāh controlled the kingdom of Buton. He made the kingdom a market of Ternate's produces, so that traders from Java, Malay, Arab countries, and China, could buy its spice goods in Buton (Amal 2010a, 86-87; Zuhdi 2010, 103). The Islamization of Buton intensified during this period. The increasing number of Muslim merchants who came to Buton for spice contributed to the process of Islamization, which had already begun in a few decades with the arrival of 'ulam $\vec{a}$ from Johor and Patani in the Malay peninsula (Zuhdi 2010, 100-101).

\section{Connecting People}

The experience of Buton, and of the other kingdoms discussed, provide us with ample evidence that Islamization contributed to making the people of the Archipelago develop a strong connection that transcended ethnic, cultural, and political lines. The kingdoms, together with the 'ulam $\vec{a}$, played a central role in unifying the people of the Archipelago under Islam. Economic relations, which had existed before the coming of Islam, strengthened and integrated new Islamic values that continue today. Thus the people of Buton share a strong collective memory about how the ruler of Ternate engaged Buton in international trade networks and hence intensified the process of Islamization. The presence of Ternate had such a strong influence that its story became part of Buton's origin myth. The ruler of Ternate, as well as of Tidore, are believed to be the older brothers of the ruler of Buton. The three brothers agreed not to attack each other, and instead sought to help and support each other. The ruler of Buton, as the youngest brother, had to send tribute to his older brother in Ternate. This story is well preserved as can be seen in the Museum Kedaton Sultan Ternate which displays a coconut shell (tempurung kelapa) that is regarded as proof of tribute from Buton's ruler to the sultan of Ternate (Zuhdi 2010, 
88-90). A harmonious relationship between Buton and Ternate was nurtured by this story, establishing Ternate's hegemony in both Buton and the world of Moluccas (dunia Maluku).

The Museum of Ternate is to some extent similar to the aforementioned springs in Bayan, Lombok, that remind the local people of the contributions that the Javanese 'ulam $\vec{a}$ made in the conversion of the Sasak people to Islam. As a result, Java has been respected as the centre of Islamic learning, where many students (santri) from Lombok attend pesantren in Java, before they continue further studies in Mecca. The respected position of Java is also recognized by the people of Ternate. The historic memory of the Islamic conversion and education of the sultan by Javanese 'ulamă from Giri-Gresik continues in the minds of the people of Ternate today. This memory remains intact because some elements of Javanese influence in Ternate still exist. In addition to the preservation of Islamic institutions within the contemporary Ternate kingdom, Babato Berjubah Putih or Babato Akhirat, in which the 'allim from Giri-Gresik Datu Mawlānā Husayn engaged in establishing, the memory of Ternate people is also cultivated by the continuing existence of a religious Javanese community, locally known as fala Jawa (Javanese hamlet), in the city of Ternate. Located close to harbour, the hamlet originates from imam Jawa mentioned above, which began in the early $16^{\text {th }}$ century. Thus fala Jawa, much like the springs in Lombok, as well as other historical memories, have become part and parcel of the identity of the people of Ternate and Lombok respectively.

Moreover, the expansion of the Ternate kingdom's territories by Sultan Bābullāh did not end in Buton. In the same year, he took over Selayar and then went to Makassar to meet the ruler of GowaTallo, Tanijallo (around 1569-1590). According to Moluccas sources (Pelras 1985, 112; Valentijn 1858, 233 Vol. 4), it is noted that Bābullāh-besides negotiating the new territorial frontiers of the two kingdoms - succeeded in converting the ruler to Islam. However, no such conversion is recognized in Makassare sources. Both lontara and oral tradition attribute the Islamization to the coming of Minangkabau 'ulamä' to South Sulawesi. As a result, it is the three Dato ('ulamä) who are alive in the memory of the people of South Sulawesi in relation to the process of Islamization; they are highly respected as the 'ulam $\vec{a}$ who greatly contributed to Islamizing the people of the region. Although they have not been elevated to the level of wali in Javanese culture, 
the graves of the three 'ulam $\vec{a}$ - in Makassar (Dato ri Bandang), in Bulukumba (Dato ri Tiro), and in Luwu (Dato ri Pattimang)-are important sites of visitation (ziyärah) for local people. They show high respect and remember the contributions the 'ulama $\vec{a}$ have made to the advancement of Islam in South Sulawesi.

In addition to South Sulawesi, Dato ri Bandang is also noted, with the name Tuan di Bandang, as the 'álim who initiated-which was carried on by Tuan Tunggang Parangan-the Islamic campaign in Kutai, Kalimantan. Although his grave is in Makassar, his name is always remembered as the 'alim who Islamized the people of Kutai and of East Kalimantan at large. With this experience, Kutai added to the list of regions in the Archipelago that had an Islamic connection with the alam Minangkabau in West Sumatra. It is however different for the people of Banjarmasin in South Kalimantan. While recognizing the important role of Minangkabau in the Islamization process, they remain grateful to the kingdom of Demak in Central Java that had converted their ruler to Islam, and at the same time helped him stay in power in the kingdom of Banjarmasin.

Minangkabau can be described as the cradle of the 'ulama' who Islamized the people of South Sulawesi and Kutai, and to some extent Ternate. As aforementioned, Minangkabau in West Sumatra had been introduced to Islam in the $14^{\text {th }}$ century with the coming of Muslim traders from west Asia, although intensive Islamization occurred when the kingdom of Aceh established political power in its west coast in the $16^{\text {th }}$ century. The Minangkabau people should therefore recognize the contributions that the Acehnese 'ulamä' had made in Islamization, given that it acted as the home of important 'alim such as Dato ri Bandang. The story of Burhān al-Dīn of Ulakan is a good illustration. His learning experience reminds the people of Minangkabau to always remember the important role of Aceh in his being recognized as the Tuanku of Ulakan, the highest title for a religious teacher in West Sumatra. Moreover, as the khalīfah of Shațāiniyah order, after his death the grave of this Tuanku of Ulakan was made into a holy place, to which Muslims from Sumatra came to perform certain Sufi rituals.

The Acehnese influence can also be ascertained from the rise of an Islamic influence in the relationship between rantau (acquired territories) — west coast areas which were under the control of Aceh kingdom - and darat (highland) in the alam Minangkabau. As the 
window to the outside world, rantau is regarded as the centre of Islam, the home of leading ulam $\vec{a}$ such as Tuanku of Ulakan who helped spread Islam (mendaki) from coastal areas to the highland (darat), the original home of the Minangkabau and therefore the source of adat (local custom). The relationship between rantau and darat is tantamount to the one between Islam and adat, which comes to be an important issue in the social and cultural dynamics of the Minangkabau world (T. Abdullah 1966, 1-25).

It is evident that Islam acts as a unifying factor for the people of the Archipelago. Knowing each other and being part of a shared religious community (umat) had already been cultivated when Islam was being introduced to populations in many areas in the region, and in turn was adopted as the majority religion of the Archipelago. Islamization created the conditions in which people with different backgroundsin terms of ethnicity, social origin, and political belonging to certain kingdoms - could experience Islamic networking and communication. These experiences were strengthened with the use of the same language and script.

\section{Language and Script}

The process of connecting people in the Archipelago was strengthened as kingdom-based process of Islamization began introducing new identity markers, most prominently Malay language with Jawi (Arabic) script. Apart from Java, where Islamic articulation occurred in Javanese language with Arabic script (pegon), almost all Muslim areas in the Archipelago increasingly used Malay with Jawi script as a medium for the expression of Islamic teachings as well as social and political affairs. In the pre-colonial period, Malay with Jawi script appeared as the lingua franca of the Archipelago, which strengthened connections among people and relationships between kingdoms. As in the case of Islamization, the rise of Malay language can be attributed to the kingdoms.

With the fall of Malacca to the Portuguese in 1511, the heart of Islamic development and the Malay language shifted to the Kingdom of Aceh. In line with its emergence as a new powerhouse of commerce, Aceh became a leading centre of Islamic politics and civilization. Muslim traders in Aceh contributed to the kingdom's central role in the trading network of Asia. Ali Mughayat Shah (reigned 1514-1530) 
was the first ruler to establish a strong foundation for the development of Aceh into the most prominent kingdom in the western part of the Archipelago in the $17^{\text {th }}$ century (Lombard 1986, 8-17; Ricklefs 2001, 62-69).

The kingdom of Aceh witnessed an important stage in the development of Malay as it became a common language in the Archipelago and beyond. The kingdoms, supported by stable political conditions and trade advancement, contributed significantly to the development of Malay language and culture. The kingdoms also witnessed intensified Islamic dynamics, alongside the growing intellectual network with the Islamic heartlands in the Middle East (Azra 2004). In this context, intellectual activities relating to Islam and Malay culture emerged in the kingdom of Aceh, which were closely linked to the efforts to contextualize Islam in the Archipelago.

This can be explained by the emergence of a new genre in the writing tradition of the Archipelago: Malay literature that contains Islamic characteristics, known as the sastra kitab. The term sastra kitab-first used by Hooykaas $(1951,144)$ and then Brakel $(1979,6)$ - refers to traditional Malay texts (hikayat) with Islamic characters or texts that came about from adapting Arabic/Persian works, not fictitious works that had developed in the Malay world. To be more specific, sastra kitab refers to religious works written in Aceh in the $16^{\text {th }}$ and $17^{\text {th }}$ centuries by leading 'ulam $\vec{a}$ ' of the kingdom-including the aforementioned Hamzah Fansuri, Shams al-Dīn al-Sumatrāīi, Nūr al-Dīn al-Ranīrī, and 'Abd al-Ra'üf Singkel—which contain Islamic teachings ranging from Sufism, jurisprudence, theology, and Islamic history. These works are commonly called kitab Jawoe in Aceh or Kitab Jawi in the Archipelago in general. The rise of sastra kitab added a special Islamic dimension to the linguistic patterns of Malay language, strengthening its use as the Islamic lingua franca in the region (I. T. Abdullah 2012, 244 Vol. 3).

Written by the leading 'ulama of Archipelago, sastra kitab are of special importance. There works are indicative of an attempt to lessen the use of Arabic vocabulary in the Malay intellectual tradition. Hamzah Fansuri, a leading Sufi 'alim of the $16^{\text {th }}$ century in the Archipelago, emphasised this point. He wanted his students to come to an exact understanding of his works. Therefore, he wrote his works in Malay, not in Arabic or Persian, writing in the opening of his work, Sharāb al-äshiqin: "so all the people who do not understand Arabic or Persian 
can comprehend it" (I. T. Abdullah 2012, 244 Vol. 3; Al-Attas 1970, 297). The same sentiment was shared by another 'álim, Shams al-Dīn al-Sumatrāīi. In his Mir'at al-mu'min, he explained that he wrote in Malay "... because they do not know Arabic and Persian but only the Pasai [a dialect in Aceh] language...” (I. T. Abdullah 2012, 244 Vol. 3). Therefore, like Hamzah Fansuri, he wrote his work in Malay to ensure that his readers in Aceh and in the Archipelago could understand the content of his work.

The Malay language Hamzah Fansuri used in his works (kitab) is categorized as pure Malay, in that it does not use Arabic extensively; Arabic is used more for certain religious terms that are difficult to translate into Malay. In addition, Hamzah Fansuri is also well-known for initiating the writing of Malay Sufi literature. He is known for using very creative language in his poetry. His use of Arabic words is prominent, but well integrated into the poetic structure. Sufi and other religious terms are not only used for the sake of rhyme and rhythm, but to also make his poems much more robust. Arabic was also used to help his readers understand Sufism (I. T. Abdullah 2012, 245 Vol. 3).

The works of the Muslim scholars described above clearly show that in the $16^{\text {th }}$ and $17^{\text {th }}$ centuries, Malay had evolved into an established language in the Archipelago, in the fields of social life, political diplomacy, commerce, and in religious intellectual discourse. The sastra kitab evidenced the use of Malay in religious writings. The ulama wrote their works in Malay so that they could be accessed more widely by Muslim audiences. However, Arabic words were still used in sastra kitab. In view of the socio-political context of the time, this is not surprising. Composing Arabicized sentences and using Arabic loan words was indicative of the high intellectual level of authors and showed that they were scholars who were sufficiently qualified in the study of religion. Van Ronkel called this pattern "Arabism". It can be compared to the contemporary use of English (I. T. Abdullah 2012, 250 Vol. 3; Ronkel 1977, 11-13). Arabism is evident in the titles of religious books in the sastra kitab, which always used Arabic even when they were Malay translations. Likewise, a number of words that are standard in Arabic-such as ahl al-șüfi (the mystic people), mutakallimin (theologians), hukamä' (jurist), falāsifah (philosopher), wujüdīyah (the existentialism), and mulhid (the apostates) — still appear but are left without a translation in Malay language. 
Therefore, the Arabic vocabulary was used to support a more precise understanding of certain aspects of Islamic doctrine. Arabic was integrated into Malay, gradually forming part of its vocabulary. Arabism in this context is an expression of the growing public appreciation of Arabic, which was used to enrich Malay with new terms that helped spread Islamic knowledge in the Archipelago.

Along with the establishment of the Malay language as the lingua franca, Jawi script also underwent a crucial development; the script was adjusted to Malay-including the standardisation of phoneme, spelling, the shift of punctuation, and the creation of acknowledged letters applied to the first and second syllables (Tjandrasasmita 2009, 292). This process, termed the systematization of Jawi spelling, established Jawi as the most prominent script of the Malay language. In the $16^{\text {th }}$ and $17^{\text {th }}$ centuries, this process of systematization can be observed in the use of Jawi script in the literary works of the period, in which a combination of Arabic script into alphabetic vocalization (alif, $w \bar{a} w$, and $y \bar{a}$ ) was used (Musa 1999, 36).

In addition to sastra kitab, which mostly refers to the development in Aceh, another important lingual development occurred in the eastern regions of the Archipelago, particularly in the kingdom of Ternate. A study by Blagden $(1930,155-73)$ analyzed two letters that were sent by the ruler of Ternate to the King of Portugal. Preserved in an archive collection in Lisbon, Spain, the letters date back to 1521 and 1522 respectively, and were written in the name of Sultan Abu Hayat, the ruler of Ternate. In this context, as Musa (1999, 41-42) asserts, the letters show the advanced use of Malay language along with its Jawi script, from the perspective of spelling and the system of vocalization. Moreover, the letters also evidence that the style of Malay used in Ternate was the same as that found in a manuscript of $16^{\text {th }}$ century Sumatra.

These letters provide strong evidence of intensive relations and networking among Muslim communities in various areas of Archipelago. They were also connected through language and script. The use of the script can be explained by the fact that Jawi-style writing developed further in some other areas of the Archipelago. In Java, including the Sundanese population in West Java, Arabic script was used in expression as well as in the spelling system of both Javanese and Sundanese. This is known as the pegon script. Many works in both Javanese and Sundanese 
are written in the Arabic pegon script, which can be traced in various manuscript catalogues of texts written in various languages in Java (Behrend 1998; Tjandrasasmita 2009, 293).

Thus, in line with increased Islamization, Malay become more widely used in the Archipelago. This development also increased cultural interaction and networking between Muslim communities in the kingdoms. The function of this network was not just limited to the Islamization of people, but also bound them by a common Malay language, Jawi script, and religious texts. The text of Täj al-salâțin is a good example that should be noted here. Written by Bukhārī alJawhārī in 1603 in Aceh, it was also of influence in other kingdoms in the Archipelago. Peter Carey $(1975,344)$ noted that it was copied in the Palace of Yogyakarta in 1831 and used-on the order of Sultan Hamengkubuwana I-as a guide for the political elites of the palace. Moreover, the text of Tāj al-salattin also inspired the writing of the Budi Istirahat Indra Bustanul Arifin in Makassar, South Sulawesi, which had the same function as the Täj al-salațīn in Yogyakarta (Pelras 1985).

The Kingdom of Buton in Southeast Sulawesi provides another important example of the development of the Malay language. Malay was the official language of the kingdom and was used for political diplomacy and trade, and in a variety of socio-religious texts. Buton's manuscript collections demonstrate this. Among the 301 manuscripts that have been collected, 102 of them were written in Malay, while 84 were written in Arabic and 75 in the local Wolio language. The colophons in the manuscripts indicate that the Malay manuscripts are older than the Arabic and Wolio ones. Malay manuscripts were written in the $17^{\text {th }}$ and $18^{\text {th }}$ centuries, whereas manuscripts written in Arabic and Wolio were produced in the $19^{\text {th }}$ century (Ikram, Hassan, and Kramadibrata 2001; Niampe 2012, 19).

The letters of the Sultan of Buton to the British and Dutch government officials are important to note here. Suryadi (2012, 286) recorded and analysed at least three letters that were written by the King of Buton to the Dutch government and one letter, on behalf of Sultan Dayyān Asrār al-Dīn, the $27^{\text {th }}$ ruler of Buton (1799-1822), addressed to the Governor General of the Dutch East Indies in Batavia. Another letter is in the name of Sultan Kaimuddin I, the $29^{\text {th }}$ ruler of Buton who was in power until 1851. The letters are part of a collection of official 
letters sent by the King of Buton that are stored in Leiden University Library. The Bodleian Library in Oxford, England, has also preserved a collection of letters of a kapitalao (sea captain) from Buton written in the $17^{\text {th }}$ century (around 1667), during the reign of the $10^{\text {th }}$ Sultan of Buton, Sultan Adilik Rahim (La Limpata or Oputa Musabuna) in 1664-1669 (Suryadi 2012, 285-86).

It is significant that these letters were written in Malay, much like the bulk of the other manuscripts and documents in the kingdom. This demonstrates that Malay had been well established as a lingua franca, and that Buton was connected to the people living in the other parts of the Archipelago.

In addition to language, the people of the Archipelago were also connected though religious thoughts recorded in kitab Jawi. A note written by an imam (religious official) of the Bacan Islands in Moluccas known as Imam Ahmad shows that he had met Snouck Hurgronje in Mecca in 1884. As Laffan (2003, 21-24) has shown, Imam Ahmad gave Snouck Hurgronje a list of books that people read in the eastern part of the lands below the winds, the territory of the kingdoms of Ternate, Tidore and Bacan. In addition to the books in Arabic that were widespread in pesantren in the late 19th century (Berg 1886), Imām Ahmad recorded a number of titles of kitab Jawi composed by the 'ulamä' from Sumatra regions. Among them is a book by 'Abd al-Ra'üf Singkel, Mir'at al-tullāb, in the form of a Malay adaptation of Ansāarìs book Fath al-wahhāb. Another book is the Dhür al-thamìm, which, according to Snouck Hurgronje, was probably written by Muhammad Nāfis al-Banjārī from Kalimantan.

The kitab composed by the Patani scholar, Shaykh Dāwud al-Fațānī (Shaykh Dāwud ibn 'Abdullāh ibn Idrīs al-Fațānī) were also included in the religious works Imām Ahmad listed. Among them were two of his books on jurisprudence: the Faräid ghäyat al-taqrīb fi al-irth wa al-tansīb about the laws that govern the division of inheritance and the I $d a b$ albāb li murìd al-nikāḥ bi al-ṣawāb about marriage. Another book in Jawi was the Sabil al-muhtadin li al-tafaqquh fì amr al-dìn, which explains the procedure for studying religion, written by Muhammad Arshad ibn 'Abdullāh al-Banjārī and the Hidayat al-sălikin-a composition in Malay based on al-Ghazālī's Bidāyat al-hidāyah — written by 'Abd alȘamad al-Palimbanī. 


\section{Closing Remarks}

The above discussions provide us with strong evidence that the kingdoms played a central role in determining Islamic dynamics in the Archipelago. In line with their role as the centres of maritime commerce, the kingdoms emerged as the heart of Islamic life, which was strengthened with the presence of 'ulam $\vec{a}$ ' in the courts. The kingdoms engaged, in one way or another, in Islamizing people. In the pre-colonial Archipelago, Islamizing activities connected people religiously and socially, which was strengthened with the wide use of Malay language with Jawi script as the lingua franca of the Archipelago. At this point, Islamization could not be viewed merely as a conversion of faith, but also as a process that had social and political dimensions. A notable aspect was the rise of a new source of identity that surpassed the diverse ethnicities, social backgrounds and language traditions across the Archipelago.

It should be acknowledged that war and political domination constituted one aspect of the process of Islamization; it featured prominently in relationships between the kingdoms and the people of the Archipelago. Islam provided the people with a new source of identity, which in turn appeared to connect them in both religious and social life. The experiences of Aceh in the western sea of Minangkabau and Gowa-Tallo in South Sulawesi are illustrative of the way that political domination as well as economic exploitation became part of the Islamizing mission. Nevertheless, this mission led the people of the Archipelago to share religious belief and social traditions. Moreover, the experience of being Islamized created collective memories that are alive in today in modern Indonesian societies that were first introduced to Islam by the 'ulamä' from particular kingdoms.

This, gradual and long historical process under Dutch colonialism became the basis for the formation of what is called an "imagined community" (Anderson 1991), establishing the modern nation of Indonesia. 


\section{Endnotes}

- I would like thank Pak Taufik Abdullah (AIPI= Akademi Ilmu Pengetahuan Indonesia) who inspired me to write about this topic, and Pak Muchlis PaEni (MSI= Masyarakat Sejarawan Indonesia) who assisted me with understanding some aspects of BugisMakassare history and culture. My thanks also go to Pak Muhammad Hisyam (LIPI) who read the draft of this article and suggested some revisions.

1. The tenth ruler of Gowa-Tallo, Tunipalangga (about 1546-1565), is reported to have bestowed a number of privileges to the Muslim community in Makassar, which consisted of traders from Campa, Patani Johor, Pahang, and Minangkabau. His successor, Tunijjalo (about 1565-1590), even built a mosque for the community in Mangallekana suburb of Makassar (Mattulada 1983, 215-16; Pelras 1985, 109).

2. As in other areas in the Archipelago, the Islamization of South Sulawesi began with formation of Muslim settlements in coastal areas. Some of the men of Bugis-Makassar, who married Muslim women as they made travel business to Islamic kingdoms in the Archipelago, took their wives back to South Sulawesi. They formed Muslim families and created a Muslim community before the conversion of ruler to Islam (Mattulada 1983, 219).

3. Nine saints (wali sanga) have gained prominence in the Javanese tradition as the great ulama or saints, who contributed to the conversion of the Javanese to Islam. The number of these saints is most likely associated with the Hindu-Javanese cosmological belief, in which nine is a very important number referring to the nine places of the nine guardian-deities who presided over the points of the compass in the old cosmological system (Drewes 1971, 297).

4. The story in the Hikayat Banjar has a strong influence due to the fact that many elements of the culture and language of the Javanese north coastal areas (pesisir), could be found in south Kalimantan (Graaf and Pigeaud 1985, 68).

5. The Islamization of Ternate by Datu Mawlānā Husayn is recounted in a legendary story. $\mathrm{He}$ is described as merchant who came to the kingdom; "he sat down in public and read out from the Quran to the public. As they listened to him, the Ternate folk became curious. ...they sensed some new magical force in the book. Thereupon they tried to imitate [writing] the characters of the book, but these they could not read. They asked the merchant how it was that they could not read them, while he could? He replied that they must first believe in God and His Apostle. They then learned the declaration of faith" (Jones 1979, 152).

6. It is believed that the three springs in Bayan arose just after Sunan Prapen put his stick in the soil of Bayan. Water came out from the land, which then become springs, as they are now (Budiwanti 2007, 289).

\section{Bibliography}

Abdullah, Imran T. 2012. "Bahasa Melayu: Lingua Franca Islam.” In Indonesia dalam Arus Sejarah, eds. Taufik Abdullah and Adrian Bernard Lapian. Jakarta: Ichtiar Baru van Hoeve.

Abdullah, Taufik. 1966. "Adat and Islam: An Examination of Conflict in Minangkabau." Indonesia (2): 1-24. 
Abdullah, Taufik, and Adrian Bernard Lapian, eds. 2012. 8 Vols. Indonesia dalam Arus Sejarah. Jakarta: Ichtiar Baru van Hoeve.

Al-Attas, Muhammad Naguib. 1970. The Mysticism of Hamzah Al-Fansuri. Kuala Lumpur: University of Malaya Press.

Amal, M. Adnan. 2010a. Kepulauan Rempah-Rempah: Perjalanan Sejarah Maluku Utara 1250-1950. Jakarta: Kepustakaan Populer Gramedia.

2010b. Portugis \& Spanyol di Maluku. Jakarta: Komunitas Bambu.

Anderson, Benedict. 1991. Imagined Communities: Reflections on the Origin and Spread of Nationalism. London: Verso.

Azra, Azyumardi. 1990. "The Surau and the Early Reform Movements in Minangkabau." Mizan 3(2): 64-85.

- 2004. The Origins of Islamic Reformism in Southeast Asia: Networks of Malay-Indonesian and Middle Eastern 'Ulamà in the Seventeenth and Eighteenth Centuries. Crows' Nest, NSW: Allen \& Unwin; Honolulu: University of Hawai'i Press.

Azra, Azyumardi, and Jajat Burhanudin, eds. 2012. Vol. 3 Indonesia dalam Arus Sejarah. Jakarta: Ichtiar Baru van Hoeve.

Battuta, Ibn. 1994. Travels of Ibn Battuta. ed. Hamilton Alexander Rosskeen Gibb. London: The Hakluyt Society.

Behrend, T. E. 1998. Katalog Induk Naskah-Naskah Nusantara Jilid 4: Perpustakaan Nasional Republik Indonesia. Jakarta: Yayasan Obor-EFEO.

Berg, L.W.C. van den. 1886. "Het Mohammedaansche Godsdienst Onderwijs Op Java En Madoera En de Daarbij Gebruikte Arabische Boeken.” TBG 31: 518-55.

Blagden, C. O. 1930. "Two Malay Letters from Ternate in the Moluccas, Written in 1521 and 1522." Bulletin of the School of Oriental and African Studies 6(1): 87-101.

Boland, Bernard Johan, and Ireen Farjon. 1983. Islam in Indonesia: A Bibliographical Survey, 1600-1942, with Post-1945 Addenda. Dordrecht: Foris Publications Holland.

Brakel, Lode Frank. 1979. "On the Origins of the Malay Hikayat." RIMA 13(2): 1-33.

Budiwanti, Erni. 2007. Islam Sasak: Wetu Telu versus Waktu Lima. Yogyakarta: PT LKiS Pelangi Aksara.

Burhanudin, Jajat. 2002. "Kesultanan.” In Ensiklopedi Tematis Dunia Islam, Jakarta: Ichtiar Baru van Hoeve.

_. 2007. "Islamic Knowledge, Authority and Political Power: The Ulama 
Ini Colonial Indonesia.” Ph.D. Thesis. Leiden University.

Carey, Peter B.R. 1975. "A Further Note on Professor Johns 'Gift Addressed to the Spirit of the Prophet." BKI 131: 341-44.

Dasgupta, Arun Kumar. 1962. "Aceh in Indonesian Trade and Politics." Ph.D. Thesis. Cornell University.

Drewes, Gerardus Willebrordus Joannes. 1971. Indonesia, Mysticism and Activism. Chicago: University of Chicago Press.

Graaf, Hermanus Johannes de, and Theodore Gauthier Th Pigeaud. 1985. Kerajaan-Kerajaan Islam Pertama di Jawa: Kajian Sejarah Politik Abad Ke-15 dan Ke-16. Jakarta: Grafitipers.

Grinter, Catherine Anne. 1979. "Book IV of the 'Bustan Us-Salatin' by Nuruddin Ar-Raniri: A Study from the Manuscripts of a 17th Century Malay Work Written in North Sumatra." Ph.D. Thesis. School of Oriental and African Studies.

Hall, Kenneth Randall. 1985. Maritime Trade and State Development in Early Southeast Asia. Honolulu: University of Hawaii Press.

Hamka. 1960. 4 Vols. Sejarah Umat Islam. Jakarta: Bulan Bintang.

Hooykaas, Christiaan. 1951. Perintis Sastra. Groningen and Jakarta: J. B. Wolters.

Ikram, Achadiati, Tjiptaningrum F. Hassan, and Dewaki Kramadibrata. 2001. Katalog Naskah Buton Koleksi Abdul Mulku Zahari. Yayasan Obor Indonesia.

Johns, Anthony Hearle. 1961. "Sufism as a Category in Indonesian Literature and History." Journal of Southeast Asian History 2(1): 10-23.

Jones, Russell. 1979. “Ten Conversion Myths from Indonesia." In Conversion to Islam, ed. Nehemia Levtzion. London: Methuen.

Kathirithamby-Wells, J. 1969. "Achehnese Control over West Sumatra up to the Treaty of Painan, 1663.” Journal of Southeast Asian History 10(3): 453-79.

Laffan, Michael Francis. 2003. Islamic Nationhood and Colonial Indonesia: The Umma Below the Wind. London and New York: Routledge and Curzon.

Lapian, Adrian Bernard. 2010. "Pengantar." In Kepulauan Rempah-Rempah: Perjalanan Sejarah Maluku Utara 1250-1950, Jakarta: Kepustakaan Populer Gramedia.

Lombard, Denys. 1986. Kerajaan Aceh: Jaman Sultan Iskandar Muda, 1607-1636. Balai Pustaka.

- 1996. 3 Vols. Nusa Jawa: Silang Budaya. Jakarta: Gramedia Pustaka Utama and École Française d'Extrême-Orient.

Mattulada. 1983. "Islam di Sulawesi Selatan." In Agama dan Perubahan Sosial, ed. Taufik Abdullah. Jakarta: YIIS \& CV Rajawali. 
Mees, Constantinus Alting. 1935. De Kroniek van Koetai: Tekstuitgave Met Toelichting. Stanford.

Musa, Hashim Haji. 1999. Sejarah Perkembangan Tulisan Jawi. Kuala Lumpur: Dewan Bahasa dan Pustaka.

Niampe, La. 2012. "Bahasa Melayu di Kerajaan Buton (Studi Berdasarkan Naskah Kuno Koleksi Abdul Mulku Zahari Di Buton).” Bahasa dan Seni : Jurnal Bahasa, Sastra, Seni, dan Pengajarannya 40(1): 14-24.

Noorduyn, Jacobus. 1956. "De Islamisering van Makassar.” Bijdragen tot de Taal-, Land-en Volkenkunde 112(3): 247-66.

Pelras, Christian. 1985. "Religion, Tradition and the Dynamics of Islamization in South-Sulawesi." Archipel 29(1): 107-35.

Pires, Tomé. 1944. The Suma Oriental of Tomé Pires. London: The Hakluyt Society.

Ras, Johannes Jacobus. 1968. Hikajat Bandjar: A Study in Malay Historiography. The Hague: Martinus Nijhoff.

Reid, Anthony. 1988. Vol. 1 Southeast Asia in the Age of Commerce, 1540-1680. New Heaven and London: Yale University Press.

- 1993. Vol. 2 Southeast Asia in the Age of Commerce, 1540-1680. New Heaven and London: Yale University Press.

Ricklefs, Merle Calvin. 2001. A History of Modern Indonesia Since C.1200. Basingstoke: Palgrave.

Roff, William R. 1985. "Islam Obscured? Some Reflections on Studies of Islam and Society in Southeast Asia." Archipel 29(1): 7-34.

Ronkel, Philippus Samuel van. 1977. Mengenal Pengaruh Tatakalimat Arab Terhadap Tatakalimat Melayu. Jakarta: Bhratara.

Said, Edward W. 1978. Orientalism. London: Penguin.

Saksono, Widji. 1996. Mengislamkan Tanah Jawa: Telaah atas Metode Dakwah Walisongo. Bandung: Mizan.

Stoianovich, Traian. 1976. French Historical Method: The Annales Paradigm. Itacha: Cornell University Press.

Suryadi. 2012. "Surat-Surat Sultan Buton, Dayyan Kaimuddin dan Kaimuddin I, Koleksi Universiteitsbibliotheek Leiden, Belanda.” Humaniora 19(3): 284 301.

Tjandrasasmita, Uka. 1977. 3 Sejarah Nasional Indonesia. Jakarta: Departemen Pendidikan dan Kebudayaan, Direktorat Sejarah dan Nilai Tradisional, Proyek Inventarisasi dan Dokumentasi Sejarah Nasional.

2009. Arkeologi Islam Nusantara. Jakarta: Kepustakaan Populer Gramedia, EFEO and UIN Jakarta. 
. 2012. "Kerajaan Islam." In Indonesia dalam Arus Sejarah, eds. Adrian Bernard Lapian and Uka Tjandrasasmita. Jakarta: Ichtiar Baru van Hoeve.

Tsuchiya, Kenji. 1990. "Javanology and the Age of Ranggawarsita: An Introduction to the Nineteenth Century Javanese Culture." In Reading Southeast Asia, ed. Audrey R. Kahin. Itacha: Southeast Asia Program, Cornell University.

Uhlenbeck, Eugenius Marius. 1964. A Critical Survey of Studies on the Languages of Java and Madura. Gravenhage: Nijhoff.

Valentijn, François. 1858. 8 Vols. Ouden nieuw Oost-Indiën. The Hague: Dordrect.

Wealthly, Paul. 1964. Impression of the Malay Peninsula in Ancient Time. Singapore: Eastern Universities Press.

Wolters, Oliver William. 1970. The Fall of Srivijaya in Malay History. Itacha and New York: Cornell University Press.

Zuhdi, Susanto. 2010. Sejarah Buton yang Terabaikan. Jakarta: Rajawali Press.

Jajat Burhanudin, Faculty of Adab and Humanities, Syarif Hidayatullah State Islamic University (UIN) of Jakarta, Indonesia. Email: j.burhanudin@uinjkt.ac.id. 


\section{Guidelines}

\section{Submission of Articles}

tudia Islamika, published three times a year since 1994, is a bilingual (English and Arabic), peer-reviewed journal, and specializes in Indonesian Islamic studies in particular and Southeast Asian Islamic studies in general. The aim is to provide readers with a better understanding of Indonesia and Southeast Asia's Muslim history and present developments through the publication of articles, research reports, and book reviews.

The journal invites scholars and experts working in all disciplines in the humanities and social sciences pertaining to Islam or Muslim societies. Articles should be original, research-based, unpublished and not under review for possible publication in other journals. All submitted papers are subject to review of the editors, editorial board, and blind reviewers. Submissions that violate our guidelines on formatting or length will be rejected without review.

Articles should be written in American English between approximately 10.000-15.000 words including text, all tables and figures, notes, references, and appendices intended for publication. All submission must include 150 words abstract and 5 keywords. Quotations, passages, and words in local or foreign languages should 
be translated into English. Studia Islamika accepts only electronic submissions. All manuscripts should be sent in Ms. Word to: http:// journal.uinjkt.ac.id/index.php/studia-islamika.

All notes must appear in the text as citations. A citation usually requires only the last name of the author(s), year of publication, and (sometimes) page numbers. For example: (Hefner 2009a, 45; Geertz 1966, 114). Explanatory footnotes may be included but should not be used for simple citations. All works cited must appear in the reference list at the end of the article. In matter of bibliographical style, Studia Islamika follows the American Political Science Association (APSA) manual style, such as below:

1. Hefner, Robert. 2009a. "Introduction: The Political Cultures of Islamic Education in Southeast Asia," in Making Modern Muslims: The Politics of Islamic Education in Southeast Asia, ed. Robert Hefner, Honolulu: University of Hawai'i Press.

2. Booth, Anne. 1988. "Living Standards and the Distribution of Income in Colonial Indonesia: A Review of the Evidence." Journal of Southeast Asian Studies 19(2): 310-34.

3. Feener, Michael R., and Mark E. Cammack, eds. 2007. Islamic Law in Contemporary Indonesia: Ideas and Institutions. Cambridge: Islamic Legal Studies Program.

4. Wahid, Din. 2014. Nurturing Salafi Manhaj: A Study of Salafi Pesantrens in Contemporary Indonesia. PhD dissertation. Utrecht University.

5. Utriza, Ayang. 2008. "Mencari Model Kerukunan Antaragama." Kompas. March 19: 59.

6. Ms. Undhang-Undhang Banten, L.Or.5598, Leiden University.

7. Interview with K.H. Sahal Mahfudz, Kajen, Pati, June $11^{\text {th }}$, 2007.

Arabic romanization should be written as follows:

Letters: ', $b, t, t h, j, h, k h, d, d h, r, z, s, s h, s, d, t, z, ', g h, f, q, l$, $m, n, h, w, y$. Short vowels: $a, i, u$. long vowels: $\overline{\mathrm{a}}, \overline{\mathrm{i}}, \overline{\mathrm{u}}$. Diphthongs: $a w$, ay. Tà marbūtāa: t. Article: al-. For detail information on Arabic Romanization, please refer the transliteration system of the Library of Congress (LC) Guidelines. 
ستوديا إسلاميكا (ISSN 0215-0492; E-ISSN: 2355-6145) بحلة علمية دولية محكمة تصدر عن مركز دراسات الإسلام والمجتمع (PPIM) بجامعة شريف هداية الله الإسلامية الحكومية بجاكرتا، تعنى بدراسة الإسلام في إندونيسيا خاصة وفي جنوب شرقي آسيا عامة. وتستهدف المجلة نشر البحوث العلمية الأصيلة والقضايا المعاصرة حول الموضوع، كما ترحب بإسهامات الباحثين أصحاب التخصصات ذات الصلة. وتخضع جميع الأبحاث المقدمة للمجلة للتحكيم من قبل للجنة غختصة.

تم اعتماد ستوديا إسلاميكا من قبل وزارة البحوث والتكنولوجيا والتعليم العالي بجمهورية إندونيسيا باعتبارها دورية علمية (رقم القرار: 32a/E/KPT/2017).

ستوديا إسلاميكا عضو في CrossRef (الإحالات الثابتة في الأدبيات الأكاديمية) منذ ع ا ـ ب، و بالتالي فإن جميع المقالات التي نشرقا مرقمة حسب معرّف الوثيقة الرقمية (DOI) . ستوديا إسلاميكا بحلة مفهرسة في سكوبس (Scopus) منذ . ب مايو 0 • ب. عنوان المراسلة:

Editorial Office: STUDIA ISLAMIKA, Gedung Pusat Pengkajian Islam dan Masyarakat (PPIM) UIN Jakarta, Jl. Kertamukti No. 5, Pisangan Barat, Cirendeu, Ciputat 15419, Jakarta, Indonesia. Phone: (62-21) 7423543, 7499272, Fax: (62-21) 7408633; E-mail: studia.islamika@uinjkt.ac.id Website: http://journal.uinjkt.ac.id/index.php/studia-islamika

$$
\begin{aligned}
& \text { قيمة الاشتر الك السنوي خارج إندونيسيا: }
\end{aligned}
$$

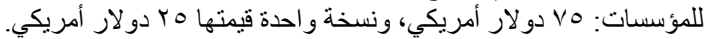

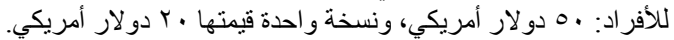

$$
\begin{aligned}
& \text { والقيمة لا تشمل نفقة الإرسال بالبريد الجويكي. }
\end{aligned}
$$

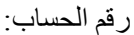

$$
\begin{aligned}
& \text { خارج إندونيسيا (دولار أمريكي): }
\end{aligned}
$$

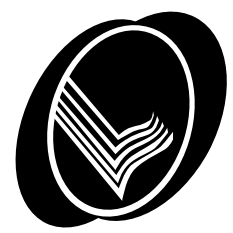




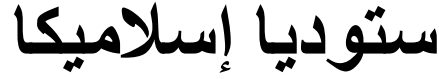 \\ مجلة إندونيسيا للار اسات الإسلامية}

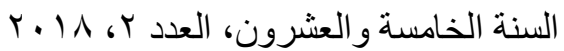

$$
\begin{aligned}
& \text { رئيس التحرير: } \\
& \text { زيوماردي أزرا } \\
& \text { مدير التحرير: } \\
& \text { أومان فنح الرحمن } \\
& \text { هيئة التحرير: } \\
& \text { سيف المزاني } \\
& \text { جمهاري } \\
& \text { ديدين شفر الدين } \\
& \text { جاجات برهان الدين } \\
& \text { فؤ اد جبلي بران } \\
& \text { علي منحنف } \\
& \text { سيف الأمم } \\
& \text { عصمة الرفيع } \\
& \text { دادي دارمادي } \\
& \text { جاجانج جهراني } \\
& \text { دين واحد } \\
& \text { ايويس نورليلاواتي } \\
& \text { مجلس التحرير الدولي: }
\end{aligned}
$$

محمد قريش شهاب (جامعة شريف هداية الله الإسلامية الحكومية بجاكرتا)

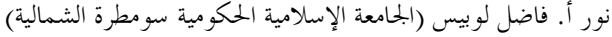
م. ش. ريكليف (جامعة أستراليا الحكومية كانبيرا)

مارتين فان برونيسين (جامعة أتريخة)

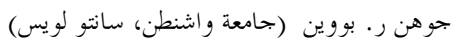

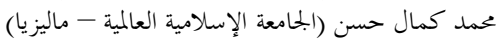

فركنيا م. هو كير (جامعة أستراليا الحكومية كانبيرا)

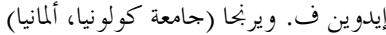

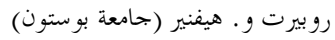

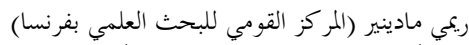

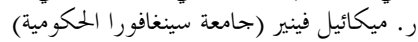

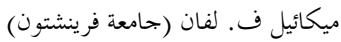

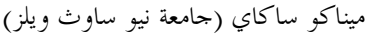

$$
\text { انابيل تيه جالوب (المكتبة البريطانية) }
$$

شفاعة المرزانة (جامعة سونان كاليجاغا الإسلامية الحكومية)

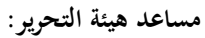

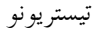

محمد نداء فضلان

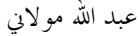

$$
\text { مراجعة اللغة الإنجليزية: }
$$

مراجعة اللغة العربية: - مان

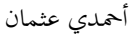

$$
\text { تصميم الغلاف: }
$$





\section{لالتوايا السالمسيا}




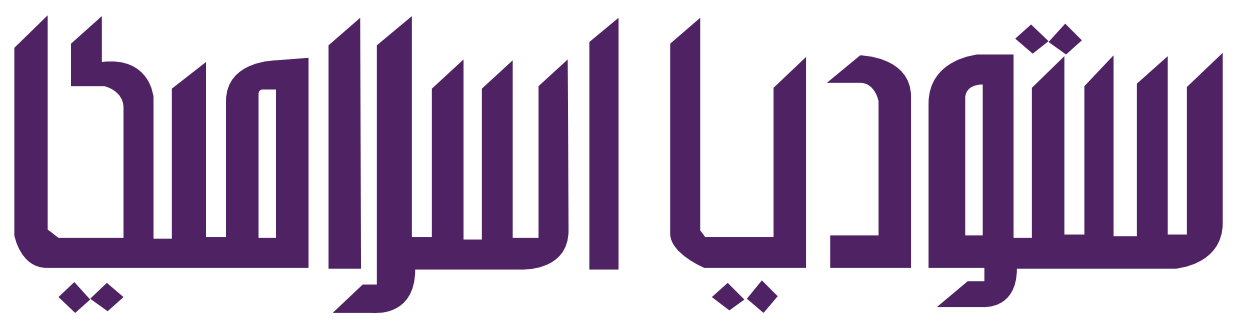

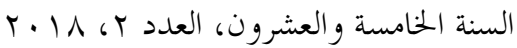

بحلة إندونيسية للدراسات الإسلامية

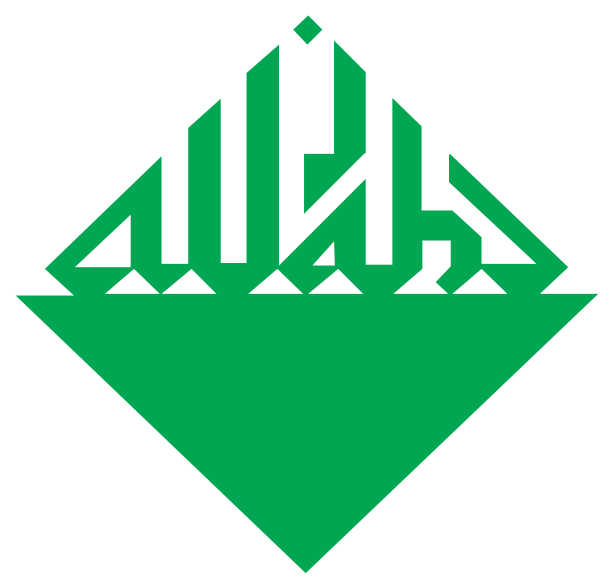

هغضلة الأنلية المسيحية

هيم الفوذ بلك الشريعة الإسلاهية

مصواري 